\title{
Consumer Attitude Towards the Cell Phone: A study on Young Generations of Chittagong Metropolitan City, Bangladesh
}

\author{
Mrs. Tanzina Chowdhury \& Mohammad Toufiqur Rahman
}

Lecturer, Department of Business Administration, International Islamic University Chittagong, Bangladesh

\begin{abstract}
Due to increased competition, locally as well as internationally, organizations need a distinguishing element that will keep consumers identifying and buying their product. This study employs to analyze the relationship between demographic variables on the brand preference and is identifying the attributes that affect the choice behavior of mobile hand set as well as why the young consumers give special emphasis to some particular factors in Chittagong metropolitan city. From the study we see that though both male and female respondents now using Nokia (57.92\%) hand set but about $50.61 \%$ of male $\mathcal{E} 59.85 \%$ of female respondent choices Samsung mobile set as their most favorite brand to next purchase because of android operating system. We also see that both newspaper (39.82\%) and television $(36.18 \%$ ) has a great influence over the respondents to choose the above mentioned mobile hand set as their favorite brand. About $67.16 \%$ of respondents are willing to spend money more than Tk. 10,000 to get the test of latest features provided by the various mobile set companies.
\end{abstract}

Keywords: Choice Behavior, Brand preference, Mobile hand set, Young consumers JEL Classification Code: L63

\section{INTRODUCTION}

$\mathrm{I}$

$\mathrm{n}$ a competitive country like Bangladesh, mobile handset companies make an optimistic effect in the consumer mind. Today like other developed and developing countries, Bangladesh has moved into the fast moving communication technologies with the help of mobile handset companies and mobile operators. Now every businessman, every job holders, most of the students, parents, most of the housewives need mobile for communication. It is impossible to move ahead without mobile handset. A mobile phone (also known as a cellular phone, cell phone, and a hand phone) is a device that can make and receive telephone calls over a radio link while moving around a wide geographic area. First and foremost it is used for - Personal Communication (Voice call, SMS \& MMS), - Business Communication (Voice call, SMS \& MMS), - Multimedia Media Applications (Radio \& MP3 Player), - Clock, Scheduler, Calculator, etc - Imaging \& internet surfing. (Rashid \& Elder 2009) Mobile handset is a highly differentiated and durable shopping product. Once upon a time, it was very rare in our country and even also in the world. It became a part of social fabric and symbol of status of upper class people in our country in the 20th Century. But now it has become progressively cheaper, affordable and part of culture for the most people in Bangladesh. In our country there are lots of mobile companies like Nokia, Samsung, SonyErricson, Motorola, Symphony, LG, Maximus, Micromax, Siemens, HTC, etc distribute their mobile handsets. Non urban and semi urban are hard core users followed by urban population. Usage of
Cell Phone amongst urban population with higher disposable income are using the product less compared to semi urban population The first hand-held mobile handset was demonstrated by John F. Mitchell and Dr Martin Cooper of Motorola in 1973, using a handset weighing around 2.2 pounds $(1 \mathrm{~kg})$. And at last, In 1983, the DynaTAC $8000 x$ was the first to be commercially available.

In tandem with the growing subscription base, sales of mobile handsets has increased at a phenomenal pace. According to BIS Shrapnel research, Bangladesh's mobile handset market is dominated by first-time users (nearly $85 \%$ ), as the country is still in its infancy in terms of mobile phone usage. Further, $80 \%$ of the handset market is dominated by ultra-low to low-end handsets, available for less than US\$68, due to the country's low per capita income levels (Priyam Shah, 2005).

The current study is aimed to explore the selected aspects of young consumers' attitude and brand choice behavior for mobile handset and also find out which factors influence the purchase decision of them as well as their overall satisfaction level Chittagong metropolitan city. Given the scope of the study, broad treatment of every aspects of brand choice behavior and their satisfaction is impossible, rather the treatment has been selective. The result of the study must be viewed more in a quantitative focus than absolute qualitative terms.

\section{Objectives of the study}

- To study the demographic profiles (age, gender, 
education and amount spent) of the respondents of mobile handset in Chittagong metropolitan city.

- To know the attributes that young consumers are using in their mobile hand set.

- To know the attributes that young consumers prefer in choosing a particular brand for their next purchase.

\section{Methodology}

A survey was conducted over 500 respondents, all the respondents are studying in colleges and universities in graduation and post graduation levels but 8 respondents from them are not taking into consideration because of insufficient data filled up by them. Out of 492 respondents, 243 are male and rests 249 respondents are female who are aged between 18-26. Chittagong region was selected as research area because researchers' working place is Chittagong and it was convenient for the researchers because data were collected by self financing. Data were collected from January to March, 2013. CDMA handsets are not included in this survey.

The present study is based on primary and secondary data as well as the primary data has been collected through self constructed questionnaire considering the objective of the study consisting of questions on multiple choice and close ended type. Data collected through questionnaire survey was checked and edited properly and finally frequency distribution, percentage of frequency of each variable was estimated.

\section{LIMITATIONS}

Every research has some limitations. In conducting this research the following limitations are faced.

- One limitation of this study is the use of a relatively small sample, only the young generations are considered here.

- This study being restricted to city of Chittagong metropolitan area which may not reflect the whole picture of Bangladesh.

- Another limitation is that some mobile handsets (Walton, Huawei Tecno, and some Chinese handsets) are not considered here.

\section{FINDINGS AND ANALYSIS}

Age and Gender of Respondents:

\begin{tabular}{|c|c|c|c|}
\hline Gender & Range of Age & $\begin{array}{c}\text { No of } \\
\text { Respondents }\end{array}$ & Percent \\
\hline Male & $19-26$ & 243 & $49.39 \%$ \\
\hline Female & $18-25$ & 249 & $50.61 \%$ \\
\hline Total & $18-26$ & 492 & $100 \%$ \\
\hline
\end{tabular}

Table 1: Age and gender of respondents

Table-1 exhibited that the entire respondents are between 18 to 26 years of age where male respondents are 243 $(49.39 \%)$ and female respondents are 249 (50.61\%). The age of the respondent shows that the survey has conducted over young generations only.

Current mobile set uses by the respondent:

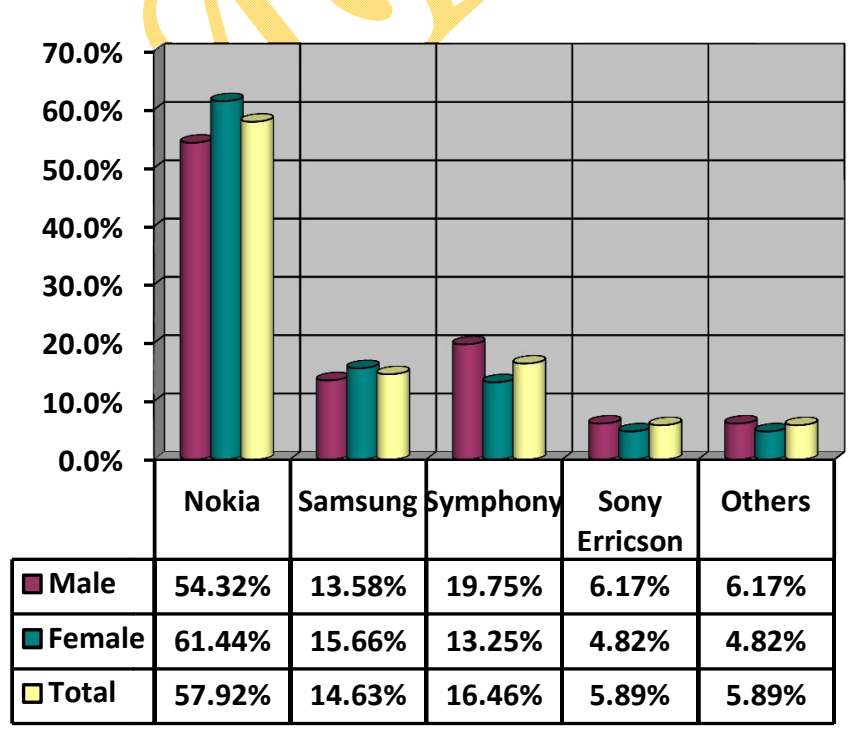

Figure 1: Mobile Handset used by the respondents at present

From the survey it is observed that both male and female respondents preferred more to Nokia (about $57.92 \%$ ) as their mobile hand set. Out of 132 are male (54.32\%) and 152 are female $(61.44 \%)$. After Nokia, male respondents use Symphony $(19.75 \%)$ \& then Samsung $(13.58 \%)$ mobile set and female respondent use Samsung (15.66\%)
\& then Symphony $(13.25 \%)$ as their mobile hand set. So Samsung users are together 72(14.63\%) and Symphony's total users are $80(16.46 \%)$. Finally 28 respondents $(5.89 \%)$ use another brand SonyErricson and rest another $5.89 \%$ uses by others likely Motorola, LG, Maximus, Micromax, Siemens, HTC, etc. 
Reasons behind the using of existing brands:

\begin{tabular}{|l|c|c|c|c|c|c|}
\hline \multirow{2}{*}{ Reasons } & \multicolumn{2}{c|}{ Male Respondents } & \multicolumn{2}{c|}{ Female Respondents } & \multicolumn{2}{c|}{ Total } \\
\cline { 2 - 7 } & $\mathrm{f}$ & $\mathrm{f}$ & $\mathrm{f}$ & $\%$ & $\mathrm{f}$ & $\%$ \\
\hline Price of the handset & 170 & $70.19 \%$ & 185 & $74.28 \%$ & 355 & $72.15 \%$ \\
\hline Durability of the handset & 136 & $56.16 \%$ & 170 & $68.20 \%$ & 306 & $62.19 \%$ \\
\hline Brand value & 204 & $84.17 \%$ & 183 & $73.53 \%$ & 387 & $78.65 \%$ \\
\hline Just for communicating & 208 & $85.60 \%$ & 224 & $89.78 \%$ & 432 & $87.80 \%$ \\
\hline GPRS & 211 & $86.78 \%$ & 225 & $90.45 \%$ & 436 & $88.61 \%$ \\
\hline Send or receive email & 99 & $40.58 \%$ & 82 & $32.79 \%$ & 181 & $36.79 \%$ \\
\hline As a modem & 141 & $58.37 \%$ & 162 & $65.15 \%$ & 303 & $61.58 \%$ \\
\hline Fast download & 110 & $45.49 \%$ & 125 & $50.33 \%$ & 235 & $47.76 \%$ \\
\hline Huge storage & 167 & $68.73 \%$ & 181 & $72.84 \%$ & 348 & $70.73 \%$ \\
\hline Taking picture and video & 135 & $55.49 \%$ & 163 & $65.33 \%$ & 298 & $60.57 \%$ \\
\hline Playing games & 37 & $15.22 \%$ & 33 & $13.17 \%$ & 70 & $14.22 \%$ \\
\hline Battery charging Capacity & 91 & $37.40 \%$ & 101 & $40.43 \%$ & 192 & $39.02 \%$ \\
\hline
\end{tabular}

Table 2: Frequency distribution of respondents both male and female (in percentage) according to the reasons behind using of existing mobile hand set

Among the different reasons in (Table-2), GPRS (88.61\%) is the main reason for choosing the above mentioned mobile handset followed by Just for communicating $(87.80 \%)$.Brand value(78.65\%), price of the handset(72.15\%), Huge storage capacity (70.73\%), durability of the handset $(62.19 \%)$, as a modem $(61.58 \%)$, taking picture and video $(60.57 \%)$, fast download $(47.76 \%)$, battery charging Capacity $(39.02 \%)$, send or receive email(36.79\%), playing games(14.22\%) are other important reasons for preferring mobile handset.

Accessories in existing handset used by the respondent:

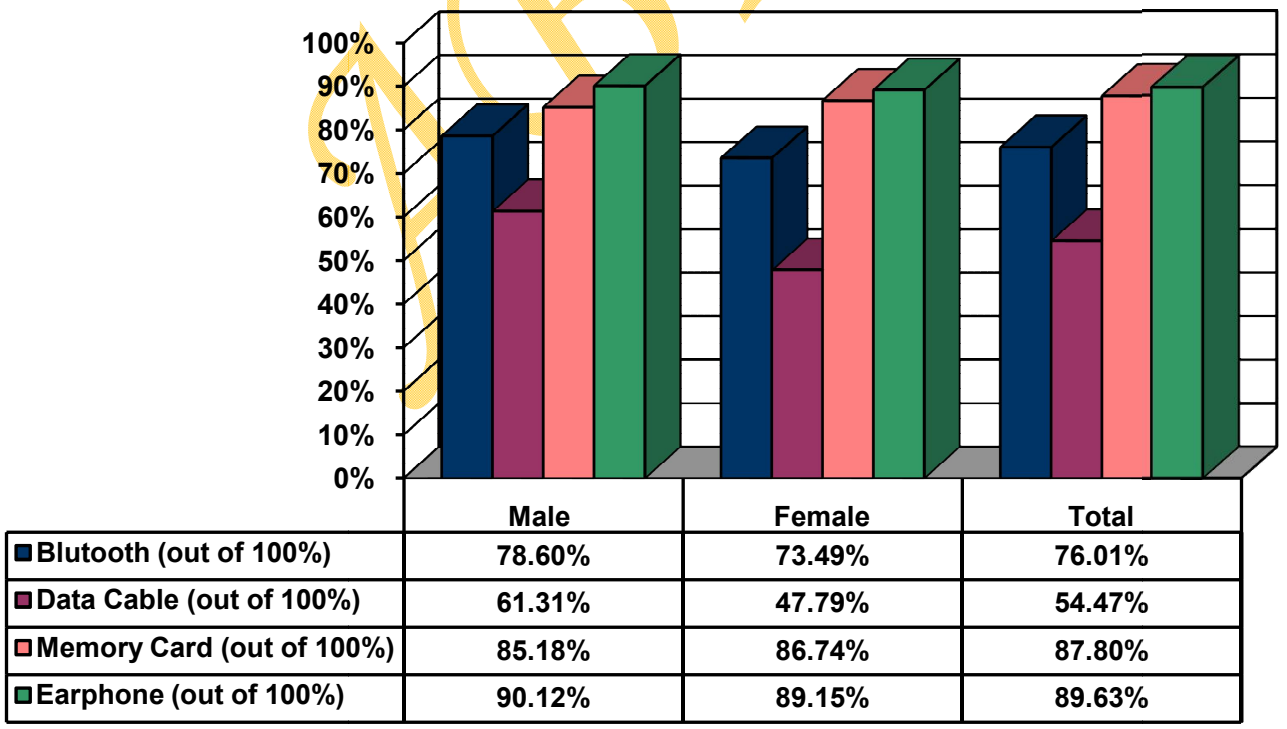

Figure 2: Frequency distribution of respondents both male and female (in percentage) using different accessories in the existing mobile handset.

Figure 2 shows that most of the respondents both male and female are frequently used the accessories like earphone $(89.63 \%)$ and memory card $(87.80 \%)$. It indicates their tendency to listening the songs, radio etc. Data cable and Bluetooth head set are also important accessories for their using. 
Asian Business Review, Volume 3, Number 3/2013 (Issue 5)

ISSN 2304-2613 (Print); ISSN 2305-8730 (Online)

Latest mobile facilities using by the consumer with their respective handset:

\begin{tabular}{|c|c|c|c|c|c|c|}
\hline \multirow{2}{*}{ Mobile Facilities } & \multicolumn{2}{|c|}{ Male Respondents } & Female Respondents & \multicolumn{2}{|c|}{ Total } \\
\cline { 2 - 7 } & $\mathrm{f}$ & $\%$ & $\mathrm{f}$ & $\%$ & $\mathrm{f}$ & $\%$ \\
\hline GPRS & 175 & $72.09 \%$ & 190 & $76.14 \%$ & 365 & $74.12 \%$ \\
\hline 3G & 28 & $11.52 \%$ & 12 & $4.81 \%$ & 40 & $8.13 \%$ \\
\hline MMS & 51 & $20.98 \%$ & 108 & $43.37 \%$ & 159 & $32.31 \%$ \\
\hline Bluetooth & 191 & $78.60 \%$ & 182 & $73.49 \%$ & 373 & $76.01 \%$ \\
\hline Video Call & 117 & $48.14 \%$ & 93 & $37.34 \%$ & 210 & $42.68 \%$ \\
\hline Design and appearance & 176 & $72.56 \%$ & 199 & $79.88 \%$ & 375 & $76.21 \%$ \\
\hline Brand image & 178 & $73.49 \%$ & 180 & $72.19 \%$ & 358 & $72.76 \%$ \\
\hline
\end{tabular}

Table 3: Frequency distribution of respondents both male and female (in percentage) expressing their latest mobile facilities by their respective handset.

From the above table-3 we see that both male and female respondents are using GPRS $(74.12 \%)$, Bluetooth device $(76.01 \%)$ as their latest mobile facilities. It indicates their interest on internet facilities to chat, networking, video call, (through Bluetooth device) internet browsing in their desktop computer or laptop as well as design and appearance $(76.21 \%)$ carrying the great importance followed by brand image $(72.76 \%)$.

Favorite brand in mobile set

Favorite brand choices for next purchase by male and female respondent:

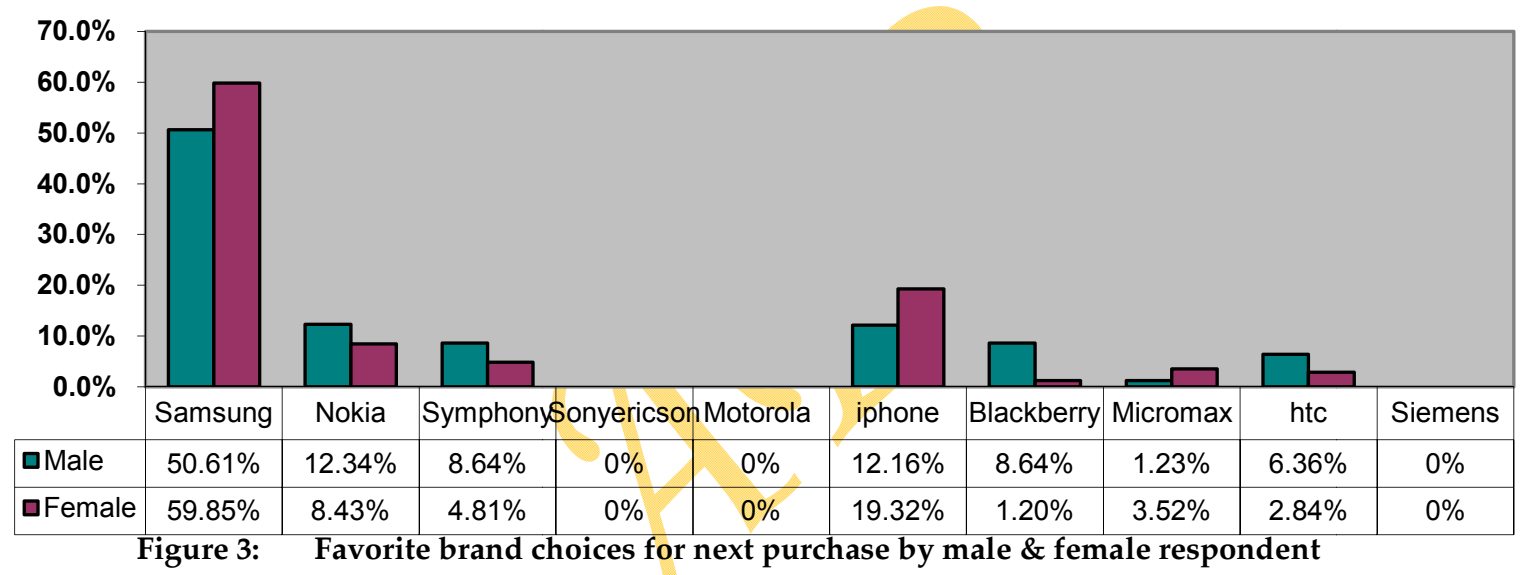

From the above figure- 3 we see that about $50.61 \%$ of male respondents choice Samsung mobile hand set as their most favorite brand to purchase because of their newly introduced high-end products, then Nokia $(12.34 \%)$, iphone (12.16\%) and Symphony $(8.64 \%)$ as their favorite brand. About 59.85\% of female respondents choice Samsung mobile set as their most favorite brand and then iphone (19.32\%) as their favorite brand to purchase This is because of android smart phone set is the main reason to choose their favorite brand.

\section{Media Influencing Respondent to Prefer Particular Brand}

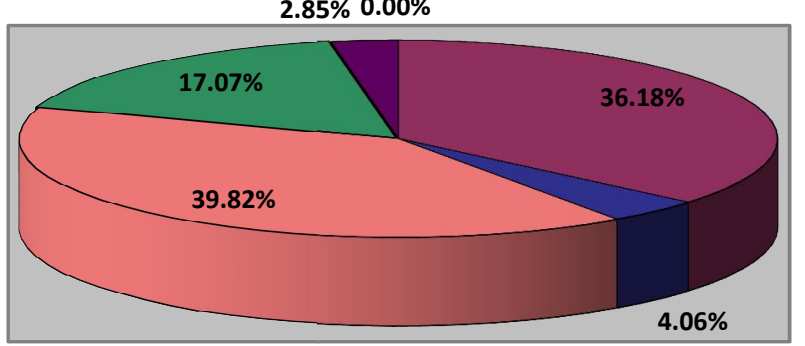

Figure 4: Media influencing respondent to prefer particular brand

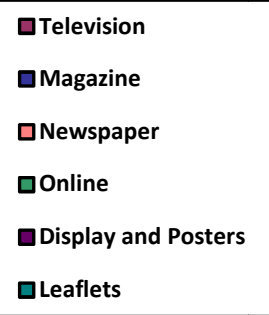

great influence over the respondents to choose the above mentioned mobile hand set as their favorite brand.
From the above figure we see that both newspaper $(39.82 \%)$ and television (36.18\%) advertisement has a 


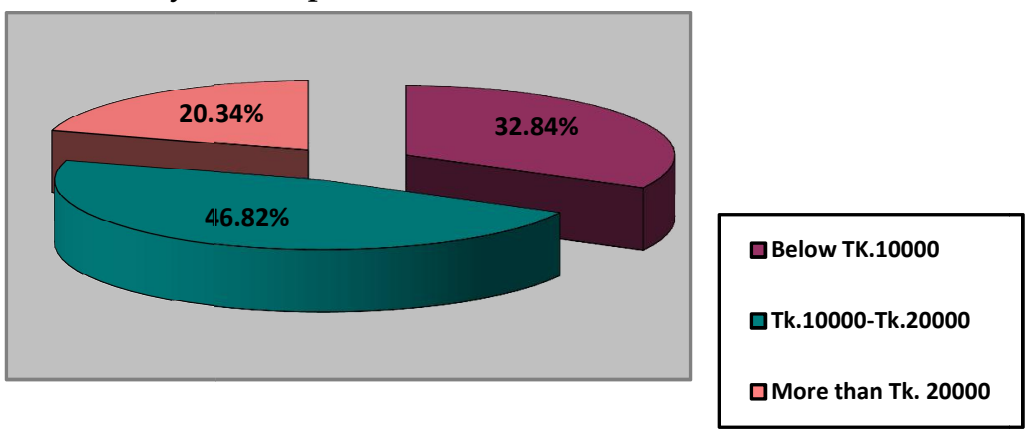

Figure 5 : Willing to pay for mobile phone set by the respondent

From the above figure we see that about $46.82 \%$ are willing to spend money between TK. 10,000-20,000 and about $20.34 \%$ of respondent are willing to spend money more than 20,000 to purchase their favorite mobile hand set. It indicates that they are willing to spend more money to get the test of latest features provided by the various mobile hand set companies.

\section{CONCLUSION}

Bangladesh is emerging as one of the fastest growing mobile hand set market across the globe. Respective of the age between 18-26, from the survey it is observed that both male and female respondents use Nokia (about $57.92 \%$ ) as their mobile hand set because of GPRS $(88.61 \%)$, Just for communicating $(87.80 \%)$, Brand value $(78.65 \%)$, price of the handset $(72.15 \%)$, Huge storage capacity $(70.73 \%)$, durability of the handset $(62.19 \%)$, as a modem $(61.58 \%)$, taking picture and video $(60.57 \%)$.

But now Samsung is found to be the most favorite brand (50.61\% of male and $59.85 \%$ of female respondents) among the mobile handsets for their next purchase decision because of their introducing features-android

\section{REFERENCES}

[1] Rashid, A. T., \& Elder, L. (2009), Mobile Phones and Development: an Analysis of IDRC-Supported Projects, The Electronic Journal of Information Systems in Developing Countries, vol. 36, no. 2, 1-16. Retrieved October 20, 2011,

[2] Bangladesh Telecommunication Regulatory Commission. (2011). Mobile Phone Subscribers in Bangladesh [Data file]. Retrieved October 24, 2011,

[3] Chinese cell phone brands, a growing threat to international titans. (2010, June 12). GLOBAL TIMES operating system and high-end products. Young respondents are ready to spend more money (near about to Tk. 20000 and more than Tk. 20000) to enjoy the different latest features. Android operating system, GPRS, Bluetooth device, Brand value, lucrative design, video calling system and respectively newspaper and television advertisement as the important attributes for preferring a specific mobile handset.

However, young respondents emphasize less importance on durability, price, others advice and opinion because of their swift switching attitude. As a whole, Samsung is competing with industry leader Nokia, Symphony, SonyErricson and other brands to grab a share of the youth market.

The findings of the study may be used as an index for improving their products and formulating marketing strategy accordingly. Future research on mobile handset market in Bangladesh, its problems and prospects could examine a wider respondents base across other cities of Bangladesh. A large sample size would also enable separate analysis across different income groups, gender and age categories.
DISCOVER CHINA, DISCOVER THE WORLD. Retrieved October 20, 2011,

[4] http://www.bd.airtel.com

[5] http://www.banglalinkgsm.com

[6] http://www.grameenphone.com

[7] http://robi.com.bd

[8] http://www.teletalk.com.bd

[9] http://www.mobileteleco.com/2010/07/micromaxlaunches-in-bangladesh-with-12.html

[10] http://www.assignmentpoint.com/science/assignme nt-on-telecommunication-industry-in-bangladesh.html

Asian Business Consortium realizes the meaning of fast publication to researchers, particularly to those working in competitive and dynamic fields. Hence, we offer an exceptionally fast publication schedule including prompt peer-review by the experts in the field and immediate publication upon acceptance. 